University of Michigan Law School

University of Michigan Law School Scholarship Repository

\title{
Enforcing the Fifteenth Amendment
}

Ellen D. Katz

University of Michigan Law School, ekatz@umich.edu

Available at: https://repository.law.umich.edu/book_chapters/134

Follow this and additional works at: https://repository.law.umich.edu/book_chapters

Part of the Constitutional Law Commons, Election Law Commons, Law and Race Commons, and the Supreme Court of the United States Commons

\section{Publication Information \& Recommended Citation}

Katz, Ellen D. "Enforcing the Fifteenth Amendment." In The Oxford Handbook of the U.S. Constitution, edited by M. Tushnet, M. Graber, and S. Levinson. Oxford Handbooks in Law. New York: Oxford University Press, 2015.

This Book Chapter is brought to you for free and open access by the Faculty Scholarship at University of Michigan Law School Scholarship Repository. It has been accepted for inclusion in Book Chapters by an authorized administrator of University of Michigan Law School Scholarship Repository. For more information, please contact mlaw.repository@umich.edu. 


\title{
Enforcing the Fifteenth Amendment
}

\author{
Ellen D. Katz \\ The Oxford Handbook of the U.S. Constitution \\ Edited by Mark Tushnet, Mark A. Graber, and Sanford Levinson \\ Print Publication Date: Oct 2015 \\ Subject: Law, Constitutional and Administrative Law, History of Law \\ Online Publication Date: Nov 2015 DOI: 10.1093/oxfordhb/9780190245757.013.18
}

\section{Abstract and Keywords}

This chapter examines efforts to enforce the Fifteenth Amendment in the period from United States v. Reese through Shelby County v. Holder. Reese and Shelby County expose the most rigorous stance the Court has employed to review congressional efforts to enforce the Fifteenth Amendment, while the years in-between show Congress and the Court working more in tandem, at times displaying remarkable indifference to blatant violations of the Fifteenth Amendment, and elsewhere working cooperatively to help vindicate the Amendment's promise. Defying simple explanation, this vacillation between cooperation and resistance captures the complex and deeply consequential way concerns about federal power, state autonomy, institutional overreaching, and race-conscious decision-making of various sorts have coalesced at particular moments. The result is a narrative that shows both the progress that is possible when the Fifteenth Amendment is vigorously enforced and the damage that is done when it is not.

Keywords: Fifteenth Amendment, United States v. Reese, Shelby County v. Holder, Congress, Supreme Court, Voting Rights Act, John Roberts, preclearance, racial discrimination, right to vote

\section{Introduction}

THE most recent Supreme Court decision to address Congress's power to enforce the Fifteenth Amendment bears a striking resemblance to its first. Separated by 137 years, United States v. Reese ${ }^{1}$ and Shelby County v. Holder ${ }^{2}$ both struck down statutes Congress had crafted to enforce the Amendment based on controversial readings of the statutes in question. Both dismissed undisputed evidence of unconstitutional racial discrimination in voting. Both announced relatively narrow holdings that ostensibly left room for Congress 


\section{Enforcing the Fifteenth Amendment}

to remedy the constitutional defect at a moment when the justices had reason to think new congressional action would not be forthcoming.

Reese and Shelby County frame nearly a century and a half of dialogue between Congress and the Court over federal power to address racial discrimination in voting. The two decisions capture the most rigorous stance the Court has employed to review congressional efforts to enforce the Fifteenth Amendment. During the years in-between, Congress and the Court have worked more in tandem, at times displaying remarkable indifference to blatant violations of the Fifteenth Amendment, and elsewhere working cooperatively to help vindicate the Amendment's promise. Defying simple explanation, this vacillation between cooperation and resistance captures the complex and deeply consequential way concerns about federal power, state autonomy, institutional overreaching, and race-conscious decision-making of various sorts have coalesced at particular moments.

This chapter examines efforts to enforce the Fifteenth Amendment in the period from Reese through Shelby County. It identifies five periods that capture the ebb and flow of Congress's efforts in this realm and the Court's varied responses to them. The result is a narrative that shows both the progress that is possible when the Fifteenth Amendment is vigorously enforced and the damage that is done when it is not. 


\section{(p. 366) I. Reconstruction and its Aftermath, 1870-1890}

Ratified in 1870, the Fifteenth Amendment provides that "[t]he right of citizens of the United States to vote shall not be denied or abridged by the United States or by any state on account of race, color, or previous condition of servitude." The new Amendment was designed to entrench federal laws that mandated race-neutral voting qualifications in the former Confederacy, while extending that practice to states in the North and West where explicit race-based exclusions persisted. The product of a compromise, the new Amendment did nothing to limit suffrage limitations based on nativity, property, education, or religious belief, nor did it reach race-based barriers to office holding. It nevertheless made clear what some had previously doubted, namely, that Congress had power to block racial discrimination that denied or abridged the franchise. The new Amendment was explicit on this point and vested Congress with power to enforce it "by appropriate legislation."3

Shortly after the Amendment's ratification, Congress invoked the enforcement power the new amendment provided. In quick succession, Congress enacted three statutes meant to address the violence and resistance African-American voters were increasingly confronting in the former Confederacy. The Enforcement Act of 1870 stated that citizens "otherwise qualified by law to vote ... shall be entitled and allowed to vote ... without distinction of race, color or previous condition of servitude." The 1870 Act set forth various penalties for public and private conduct that interfered with voting, and two acts passed the following year bolstered the initial law with additional penalties and improved enforcement mechanisms. ${ }^{4}$

The first challenge to these Acts was soon to come. United States v. Reese arose after an African-American man named William Garner was unable to vote in a municipal election held in Lexington, Kentucky, on January 31, 1873. State law required voters to pay a poll tax in advance of the election. Garner had tried to do so, but the city tax collector had refused to accept payment "on account of the race and color of Garner." Garner accordingly attempted to vote on Election Day by presenting an affidavit attesting to his efforts to pay the tax. Hiram Reese and Matthew Foushee were election inspectors who, over the dissent of a colleague, refused to let Garner vote. ${ }^{5}$

Federal indictments followed that charged Reese and Foushee with violating sections 3 and 4 of the 1870 Act. Section 3 provided that "the offer" of a citizen to carry out a statemandated prerequisite to voting was "performance in law of such act" should an election official wrongfully prevent that offer from being "carried into execution." ${ }^{6}$ Section 4 made it a criminal offense "wrongfully [to] refuse or omit to receive ... the vote of such (p. 367) citizen," or to prevent a citizen "from doing any act required to be done" to "qualify him to vote or from voting at an election as aforesaid." 7 


\section{Enforcing the Fifteenth Amendment}

Reese and Foushee challenged the indictments, maintaining that sections 3 and 4 of the 1870 Act were not "appropriate legislation" enforcing the Fifteenth Amendment. The Supreme Court agreed. Chief Justice Waite's majority opinion observed that "Congress can interfere" in state elections only when a state "wrongful[ly] refus[es] to receive the vote of a qualified elector ... because of race, color, or previous condition of servitude." The chief justice read sections 3 and 4 to reach beyond such race-based denials to encompass wrongful denials of the vote more generally. He wrote that section 3 "does not in express terms limit the offense ... to a wrongful discrimination on account of race," and that section 4 similarly contained "no words of limitation, or reference even, that can be constructed as manifesting any intention to confine its provisions to the terms of the Fifteenth Amendment." 8

Without doubt, there were better ways to read the statute. The first section of the 1870 Act explicitly recognized the racial component the chief justice said was missing. It specified that qualified citizens must be allowed to vote "without distinction of race, color, or previous condition of servitude." ${ }^{9}$ Sections 3 and 4 described statutory offenses based on the wrongful conduct "aforesaid." 10 There was, moreover, no dispute that Congress enacted the statute to address the race-based violence and discrimination black voters were confronting in the South. ${ }^{11}$ And there was no doubt that the defendants themselves had blocked a voter based on a "distinction of race," which meant the statute was constitutional as applied to them.

A simple drafting change would have cured the legal deficiency Reese identified, but that change was not implemented. Reese, along with United States v. Cruikshank, ${ }^{12}$ which the Court decided the same day and which identified an analogous legal error in the applicable indictments, ${ }^{13}$ was issued at a moment when political support for federal intervention in the South was waning. ${ }^{14}$

As a matter of constitutional law, however, Reese and Cruikshank did nothing to circumscribe Congress's power to enforce the Fifteenth Amendment. Despite the Court's uncharitable reading of the statute and indictments, the two decisions never questioned Congress's power to enforce the Fifteenth Amendment with decidedly intrusive measures, including ones that supplanted state law and "substitute[d] ... performance wrongfully prevented (p. 368) for performance itself." ${ }^{15}$ Nor did either decision doubt Congress's power to reach private action when enforcing the Amendment, even though that power had been challenged in both cases, and Cruikshank deemed the absence of state action as sufficient grounds to dismiss separate counts brought under the Fourteenth Amendment. ${ }^{16}$

These omissions may, of course, reflect nothing more than that the Court had already dispensed with the voting claims on other grounds. ${ }^{17}$ Yet both cases presented the Court with the opportunity to limit congressional power, and in both cases it declined to do so, leaving open the possibility that Congress possessed these broad powers. Judging by a 


\section{Enforcing the Fifteenth Amendment}

later case, moreover, this willingness may have reflected more than just opportunistic restraint.

Eight years after Reese, the Court addressed Congress's power to regulate privately orchestrated, racially motivated, election-related violence. The defendants in Ex parte Yarbrough ${ }^{18}$ had assaulted a black man to keep him from voting in the 1882 congressional elections. The defendants challenged their convictions, arguing, among other things, that Fourteenth Amendment precedent blocked Congress from reaching private conduct. ${ }^{19}$ But the Yarbrough Court disagreed. Observing that the cited cases addressed Congress's ability to protect "mere invasions of private rights," 20 Yarbrough held that Congress possessed distinctly broad power to protect foundational rights "essential to the healthy organization of government itself." Absent this power, "the very sources of power may be poisoned by corruption or controlled by violence and outrage, without legal restraint ... ." ${ }^{21}$ Put differently, states needed healthy representative institutions to govern responsibly, and thus Congress needed the power to ensure such institutions existed and were maintained. ${ }^{22}$

In so holding, Yarbrough was building on Strauder v. West Virginia, ${ }^{23}$ which held that a state law barring black men from jury service violated the equal protection clause. Although the Fourteenth Amendment had not previously been understood to cover "political" rights such as jury service, ${ }^{24}$ Strauder observed that the law inexorably denied black citizens excluded from the jury "the privilege of participating fully ... in the administration of justice $" 25$ and threatened to deny black defendants impartial treatment. Strauder thereby suggested that protecting the right to race-neutral jury service might also protect the rights of black defendants. ${ }^{26}$ In other words, Strauder sought "to create the institutions necessary for the vindication of private rights." 27

(p. 369) Yarbrough, likewise, recognized the need to foster institutions necessary for healthy governance, but understood Congress to be the critical actor in this project. The Court deemed the provisions of the Enforcements Act under which the Yarbrough defendants had been convicted appropriate measures to protect "the exercise of rights ... essential to the healthy organization of government itself." 28 The decision, moreover, invited Congress to remain vigilant and aggressively police the political process so as to vindicate foundational rights.

For a brief moment, Congress appeared inclined to accept this invitation. Following Republican victories in 1888, a new bill was introduced to revive the Enforcement Acts and expand federal power to supervise elections, guard against fraud and intimidation, and remedy violations that occurred. But this bill died in the Senate in 1891 as competing priorities divided and distracted its Republican supporters. ${ }^{29}$ Decades passed before Congress would again take up Yarbrough's invitation to protect the right to vote. ${ }^{30}$ 


\section{Dormancy: Non-enforcement of the Fifteenth Amendment, 1890-1965}

Beginning in Mississippi in 1890 and culminating in Georgia in 1908, the former Confederate states either held constitutional conventions or sponsored referenda deliberately crafted to limit voter participation. The principal goal of these efforts was to entrench white supremacy, as their supporters proudly announced. ${ }^{31}$ By design, these efforts also entrenched one-party Democratic rule and the interests of the party's wealthiest, landowning members. ${ }^{32}$ In the years that followed, scores of onerous and deceptive hurdles were erected to block African-American voters and a host of poor white voters from registering and casting ballots.

Both Congress and the Court responded with remarkable indifference. For a time, the Committee on Elections within the House of Representatives continued to review disputed congressional elections marked by violence, fraud, or discriminatory practices. It even periodically refused to recognize the nominal winner and ordered that the defeated candidate be seated. But these efforts were short-lived, ${ }^{33}$ and Congress as a whole showed little interest in resisting the disenfranchisement project under way in the Southern states. A bill (p. 370) to revive enforcement died in 1891, and by 1894, Congress voted to repeal substantial portions of the 1870 and 1871 Acts. ${ }^{34}$

Nine years later, the Court scrapped one of the surviving provisions of the 1870 Act. What had been section 5 established criminal penalties for "any person" who, through bribery or threats, hindered the exercise of voting rights as guaranteed by the Fifteenth Amendment. ${ }^{35}$ James $v$. Bowman ${ }^{36}$ deemed the provision unconstitutional, holding that Congress could not reach purely private action when enforcing the Fifteenth Amendment. ${ }^{37}$ In so holding, the Court relied on the very Fourteenth Amendment precedent Yarbrough had distinguished a quarter century earlier. ${ }^{38}$ The James decision thereby turned its back on the expansive vision of congressional power Yarbrough had advanced, and the mandate to act that had accompanied it. No longer did the justices see any meaningful difference between Congress's power to address "mere invasions of private rights" and its power to protect "the exercise of rights ... essential to the healthy organization of government itself." 39 The theory of a special federal power to ensure the proper functioning of the state political process was gone.

Concurrently with James v. Bowman, the Court turned back a Fifteenth Amendment challenge to the registration requirements mandated by the 1901 Alabama Constitution. Montgomery resident Jackson Giles brought the case on behalf of himself and other black men who attempted to register but "[were] refused arbitrarily on the ground of [their] color ... while all white men were registered." 40 The Court insisted that it had no power to grant meaningful relief, largely because it was convinced that granting Giles the relief he sought would do him no good. According to Justice Holmes, insofar as "the great mass of the white population intends to keep the blacks from voting ... a name on a piece of paper 


\section{Enforcing the Fifteenth Amendment}

will not defeat them." ${ }^{41}$ Giles should instead seek relief for this "great political wrong" from either Alabama itself or from the "legislative and political department[s]" of the federal government. ${ }^{42}$

Absent the vote, Giles had little chance of securing meaningful relief in Alabama, although he did try. ${ }^{43}$ Congress had no interest in helping, either. The year after Giles, the House Committee on Elections announced it was withdrawing from adjudicating congressional election disputes. The Committee explained that to declare a victor "not elected" because of "the disfranchisement of the colored vote" would be "precedent for unseating nearly every member of the House" from the former Confederate states. ${ }^{44}$ Channeling Giles in a perverse Catch-22, the Committee instructed those citizens who found themselves (p. 371) unlawfully denied a ballot to file suit, and "carry it, if necessary, to the Supreme Court," which it said was the proper forum to deal with such issues. ${ }^{45}$ Congress followed up in 1909 and again in 1911, by repealing all but three of the remaining sections of the 1870 and 1871 Enforcement Acts. ${ }^{46}$

As a group, Southern whites were, at the time, less supportive of onerous voting restrictions than Justice Holmes indicated in Giles. Responsible pushback from Congress and the Court might well have displaced the new state measures. ${ }^{47}$ Instead, the restrictions remained in place without serious federal challenge, with the result that these measures achieved the massive disenfranchisement and the white domination in representation they were designed to promote. Justice Holmes's claim about the preferences of the white population may have been empirically false when he said it, but it became a self-fulfilling prophecy.

The result was a diminished electorate. Coupled with more modest and segmented franchise restrictions in the North and West, ${ }^{48}$ this newly constrained electorate ensured Congress would remain indifferent to disenfranchisement for decades. Fueling this indifference was ever-worsening malapportionment and the Court's insistence that this problem was nonjusticiable. ${ }^{49}$ Nor did the justices help matters when, in 1937, they voted to uphold the poll tax against Fourteenth and Nineteenth Amendment challenges. ${ }^{50}$ Due largely to Southern opposition, proposals for Congress to outlaw the poll tax in federal elections made little progress. ${ }^{51}$

Still, the Court managed periodically to deploy the Fifteenth Amendment to provide isolated relief. Giles notwithstanding, it found sufficient authority to strike down Oklahoma's notorious grandfather clause as a blatant violation of the Fifteenth Amendment, and to scrap the invidious replacement the state concocted for it. ${ }^{52}$ The Court also deemed later iterations of Texas's infamous white primary to run afoul of the Fifteenth Amendment, and, in 1944 and again 1953, invalidated variations on the practice. ${ }^{53}$ The Court read the Fifteenth Amendment to preclude an Alabama gerrymander that removed almost every African-American resident from the city of Tuskegee. ${ }^{54}$ The later decisions provided some relief, and African-American voter registration, particularly in cities, climbed slowly in their wake. ${ }^{55}$ 


\section{Enforcing the Fifteenth Amendment}

(p. 372) As it did, a broader attack on the South's Jim Crow regime had begun. The Supreme Court's decision in Brown v. Board of Education was followed by the Montgomery Bus boycott of 1955-1956, after which Congress enacted its first civil rights law since 1875. Shepherded to passage by Texas senator Lyndon Baines Johnson, the Civil Rights Act of 1957 was a modest measure that empowered the attorney general to seek injunctive relief when enforcing voting rights, expanded the ability of federal courts to hear such actions, and made changes within the Justice Department that allowed for the creation of the Civil Rights Division. ${ }^{56}$ The Civil Rights Act of 1960 added recordkeeping requirements that increased federal power to inspect and monitor registration practices, and thus brought discriminatory practices into better view. ${ }^{57}$

Time-consuming lawsuits followed that yielded hard-fought victories but little progress on voting rights. State and local officials replaced invalidated electoral practices with new discriminatory measures that would require more litigation to displace. As explicit racial lines fell on buses, at lunch counters, and, after the massive 1964 Civil Rights Act, in public accommodations generally, African-American voters in the South continued to confront significant obstacles when they attempted to register and vote. ${ }^{58}$

\section{Determined Enforcement, 1965-1986}

In March 1965, televised protests in Selma, Alabama vividly captured the depth of Southern resistance to ending race-based disenfranchisement, ${ }^{59}$ and prompted President Johnson to call on Congress to enact a new voting law. Observing that what happened in Selma was part of a "far larger movement" seeking equality and "the full blessings of American life," President Johnson invoked the language of the civil rights protestors, and famously stated, "[t]heir cause must be our cause, too. Because it is not just Negroes, but really it is all of us, who must overcome the crippling legacy of bigotry and injustice. And we shall overcome." 60

Congress responded with the Voting Rights Act of 1965 (VRA). Often labeled the "crown jewel" of the civil rights movement, ${ }^{61}$ the VRA targeted the most recalcitrant and discriminatory jurisdictions and subjected them to intrusive requirements designed to secure African-American access to the ballot. ${ }^{62}$ Passage of the statute launched an era in which Congress aggressively enforced the Fifteenth Amendment. Congress repeatedly reauthorized its provisions and expanded its reach. And the Court was steadfast in Congress's support, both by recognizing exceptionally broad congressional power to act and concurrently adopting a more capacious conception of the right to vote.

Among the VRA's most notable features was the manner in which it targeted jurisdictions in which disenfranchisement was most widespread. Section 4(b) designated jurisdictions "covered" if they used a "test or device" to limit registration or voting, and less than half the jurisdiction's eligible citizens were either registered to vote on November 1, 1964, or actually cast ballots in the presidential election that year. ${ }^{63}$ Section 4 (a) prohibited 


\section{Enforcing the Fifteenth Amendment}

(p. 373) jurisdictions covered under 4(b) from denying the right to vote to any person who failed to comply with a test or device. ${ }^{64}$ Section 5 required that covered jurisdictions obtain federal approval, known as "preclearance," before changing any aspect of their voting rules, and specifically, demonstrating that the changes they proposed were not discriminatory in purpose or effect. ${ }^{65}$

South Carolina was one of the seven states initially covered by the 4(b) formula. ${ }^{66}$ It quickly brought suit seeking to scrap the statute as an "unjustified" and "arbitrary" affront to the "Equality of Statehood" principle, and a "usurp[ation]" of the State's legislative and executive functions. ${ }^{67}$ The Warren Court disagreed. South Carolina v. Katzenbach recognized extensive congressional power to craft "inventive" remedies to address systematic racial discrimination in voting. ${ }^{68}$ The 4 (b) coverage formula was "rational in both practice and theory," capturing the places where "Congress was ... entitled to infer a significant danger of ... evil." ${ }^{69}$ Section 4(a)'s suspension of the use of tests and devices was a "legitimate response" to their discriminatory use. ${ }^{70}$ Section 5 's preclearance requirement was justified because Congress "had reason to suppose" that preclearance was needed to block evasive, discriminatory moves. Based on the record before it, Congress could lawfully choose to "shift the advantage of time and inertia from the perpetrators of the evil to its victims." ${ }^{71}$ Justice Black dissented alone, arguing that preclearance impermissibly rendered covered states "little more than conquered provinces." 72

South Carolina v. Katzenbach addressed Congress's power to enforce the Fifteenth Amendment, but the Court soon made clear that Congress enjoyed similarly expansive power under the Fourteenth Amendment. ${ }^{73}$ Katzenbach v. Morgan recognized this power when it turned back a constitutional challenge to section 4(e) of the VRA, which barred states from using English literacy as a prerequisite to voting for graduates of designated non-English-language schools. ${ }^{74}$ Unlike the provisions upheld in South Carolina $v$. Katzenbach, section 4(e) was a late addition to the statute and lacked a supporting evidentiary record documenting the problem it purported to address. The provision, moreover, did not target a practice in the Jim Crow South but instead the way in which New York's English literacy requirement functioned to disenfranchise large segments of New York City's Puerto Rican community. ${ }^{75}$

Despite these differences, Katzenbach v. Morgan ${ }^{76}$ readily upheld Congress's power to enact section 4(e). Requiring neither concrete evidence nor specific congressional findings of any sort, the Court deemed it sufficient that Congress "might well have questioned" the facially neutral justifications the state proffered for its literacy requirements, ${ }^{77}$ and that (p. 374) the Court could "perceive a basis upon which the Congress might resolve the conflict as it did." 78 The Court observed that Congress might have concluded both that New York's requirement itself constituted "invidious discrimination in establishing voter qualifications," 79 and that it fostered "discrimination in governmental services." ${ }^{80}$ Morgan stated: "It is not for us to review the congressional resolution" of the factors that informed that judgment. ${ }^{81}$ The decision thus endorsed vast 


\section{Enforcing the Fifteenth Amendment}

congressional power to enforce the amendment, and, arguably, to interpret the scope of the rights it protected as well. ${ }^{82}$

Bolstered by these judgments and broad statutory constructions the Court gave to the regime, ${ }^{83}$ the VRA proved to be remarkably effective. Indeed, its impact was immediate and sweeping. By the end of 1965, many thousands of black voters had registered, and by 1970, African-American turnout has risen dramatically. ${ }^{84}$ Before long, federal judges were noting that black voters were registering and voting "without hindrance" in covered jurisdictions. ${ }^{85}$

The VRA was slated to expire after five years, but Congress voted to extend the regime. Reauthorizations in 1970 and again in 1975 updated the section 4(b) coverage formula to include voter participation data from elections in 1968 and 1972 respectively. ${ }^{86}$ Congress also voted to suspend literacy tests nationwide, and not just in covered jurisdictions, first for five years, ${ }^{87}$ and then permanently. ${ }^{88}$ It also added significant new protections for language minorities.

The Court upheld Congress's power to extend the statute in these ways. ${ }^{89}$ In Oregon v. Mitchell, Justice Hugo Black thought the nationwide ban on literacy tests was constitutional because Congress "could have concluded" that discrimination in education leaves some voters less equipped than others to pass the tests. ${ }^{90} \mathrm{Justice}$ William J. Brennan Jr. likewise saw a basis "upon which Congress could have" found literacy tests have discriminatory effects due to past discrimination in education. ${ }^{91}$ Justice Potter Stewart preferred a national ban to a geographically selective one, deemed it "reasonable" and "appropriate" legislation, and saw no need for evidence showing that the tests "unfairly burden[]" minority voters or "state-by-state findings" of any sort. After all, "Congress may paint with a much broader brush than may this Court."92

In 1980, the Court again upheld the constitutionality of the VRA as reauthorized, albeit now in a sharply divided decision. City of Rome v. United States ${ }^{93}$ arose when city officials challenged a denial of preclearance made pursuant to the 1975 reauthorization, arguing, inter alia, that Congress lacked power to ban implementation of electoral practices that were discriminatory only in effect. ${ }^{94}$ Mobile v. Bolden, ${ }^{95}$ decided the same day as (p. 375) City of Rome, made clear that public conduct does not violate the Fourteenth or Fifteenth Amendments simply because it has a racially disproportionate impact. ${ }^{96}$ City of Rome held that Congress could nevertheless proscribe implementation of electoral changes in covered jurisdictions that were discriminatory solely in effect. Citing South Carolina v. Katzenbach, ${ }^{97}$ the Court noted that such state action, although constitutional, may "perpetuate[] the effects of past discrimination," and "create the risk of purposeful discrimination" 98 in covered jurisdictions. Three justices disagreed, claiming the VRA was unconstitutional under this approach. ${ }^{99}$

Congress responded to both City of Rome and Mobile v. Bolden in 1982. A contentious debate pitted support for restoring the regime to its pre-Mobile contours against those concerned that a purely effect-based proscription would necessarily devolve into proportional representation. The amendments that resulted extended the preclearance 


\section{Enforcing the Fifteenth Amendment}

regime for twenty-five years and, in response to objections voiced by the dissenters in City of Rome, expanded opportunities for covered jurisdictions to "bail out" from the preclearance requirements. Most notably, the 1982 amendments significantly altered section 2 of the VRA. Once thought to be coextensive with the Fifteenth Amendment, the provision was amended to proscribe any voting practice that "results in a denial or abridgement" of the right to vote based on race or membership in designated language minority communities. ${ }^{100}$ Rather than a pure disparate impact test, the new provision mandated a complex inquiry derived from foundational cases defining racial vote dilution in which many factors are relevant, and none dispositive. ${ }^{101}$

This multi-factored section 2 inquiry quickly led to disagreements among federal courts adjudicating claims under the new provision. In 1986, Thornburg v. Gingles sought to clarify the circumstances under which section 2 liability exists. ${ }^{102}$ Gingles did so by distilling three "preconditions" to a section 2 claim, namely, that plaintiffs must demonstrate that the minority group is "sufficiently large and geographically compact to constitute a majority in a single member district," and that both minority and white voters vote cohesively and in opposition to one another. ${ }^{103}$ After Gingles, plaintiffs who made these showings typically prevailed. ${ }^{104}$

Gingles identified circumstances likely to give rise to liability under section 2, while leaving unresolved how violations of section 2 might be remedied. ${ }^{105}$ The framework Gingles established nevertheless invited the creation of majority-minority districts both to remedy and to avoid section 2 violations. ${ }^{106}$ Gingles also prompted covered jurisdictions (p. 376) to include more majority-minority districts in proposed districting plans than they had previously, to secure compliance with section 5.107 They did so because compliance with section 5 was understood to require compliance with section 2 (at least until the Court ruled otherwise in 1997); ${ }^{108}$ because the majority-minority districts addressed specific concerns arising under section 5, and because the Department of Justice repeatedly denied preclearance to redistricting plans the agency thought contained too few majority-minority districts. ${ }^{109}$

As a result, districting plans began including a larger proportion of majority-minority districts than they once had. Voters in these districts largely, albeit not exclusively, elected minority candidates to office ${ }^{110}$ By the mid-1990s, more minority representatives were serving on school boards, city councils, state legislatures, and in the U.S. House of Representatives than at any time since Reconstruction. ${ }^{111}$

\section{Stasis and Skepticism, 1986-2005}

Congress took no action in response to Gingles and the framework it imposed on section 2 and the VRA. Content to leave interpretation and implementation of the 1982 VRA amendments to others, Congress made no changes to the regime for the duration of the 


\section{Enforcing the Fifteenth Amendment}

Rehnquist Court. It enacted a host of new civil rights and non-race-related voting laws during this period, ${ }^{112}$ but it would not address the VRA again until it set out to reauthorize its expiring provisions beginning in 2005.

The Rehnquist Court, by contrast, addressed the VRA repeatedly and skeptically. To be sure, skepticism about the VRA predated William Rehnquist's 1986 confirmation as chief justice, ${ }^{113}$ but under his leadership, and as new justices appointed by Presidents Reagan and George H.W. Bush joined the Court, a reluctant stance toward the constitutional underpinnings and effects of federal intervention mandated by the VRA made its way into majority opinions with increasing frequency. The Rehnquist Court was particularly uneasy about the proliferation of majority-minority districts and the type of political participation it thought they fostered. ${ }^{114}$ The Court accordingly pursued a steady and determined project to rein in the regime and restrict use of the majority-minority district.

It did so in two related ways. First, the Court consistently read the VRA narrowly, thereby limiting the instances in which liability might arise and a new majority-minority (p. 377) district might be required. ${ }^{115}$ The Court also recognized a new "analytically distinct" injury under the equal protection clause that arose when jurisdictions created oddly shaped majority-minority districts that were not absolutely required by the VRA. ${ }^{116}$ This new constitutional injury blunted the incentive to draw majority-minority districts prophylactically to avoid liability under the VRA. Taken together, these steps scaled back the VRA's reach and reduced opportunities to employ its dominant remedy.

And yet, even as the Rehnquist Court cabined the VRA, the Court concurrently affirmed, with surprising vigor, Congress's power to craft remedies for racial discrimination in voting. Notably, the Court did so at the same time it was placing significant curbs on Congress's power to craft civil rights remedies that did not implicate race and the right to vote. ${ }^{117}$

The Rehnquist Court's principal turn against federally legislated civil rights remedies began in 1997 when City of Boerne v. Flores struck down the Religious Freedom Restoration Act because the act lacked "congruence and proportionality between the injury to be prevented or remedied and the means adopted to that end."118 The Court held that RFRA was not "appropriate legislation" within the meaning of section 5 of the Fourteenth Amendment because the constitutional injuries it purported to address were too few in number, and it lacked sufficient connection to the rules the statute imposed on state and local governments. ${ }^{119}$ As the Court saw it, RFRA was not an attempt to enforce rights the Court had identified as constitutionally protected but instead an attempt by Congress to declare the content of constitutional rights themselves. City of Boerne held that, with this attempt, Congress overstepped its enforcement authority.

By 2001, five more federal statutes had fallen under the new "congruence and proportionality" standard. ${ }^{120}$ Applying rigorous review, the Court deemed linkages between statutory proscriptions and constitutional injuries too attenuated, statutory remedies too broad, and underlying congressional findings too skimpy to render various statutory provisions valid exercises of Congress's enforcement power. Boerne and its 


\section{Enforcing the Fifteenth Amendment}

progeny made clear that Congress could rely on neither general assertions nor isolated examples of unconstitutional conduct, but instead valid enforcement legislation needed to rest on a record documenting a widespread pattern of such conduct by the entities subject to suit. ${ }^{121}$

This rigorous review differed markedly from the approach the Court took when it had previously upheld Congress's exercise of its enforcement powers in crafting the VRA. The (p. 378) early cases upholding the VRA all deferred to Congress's judgments regarding the need for particular remedies, including ones that intruded deeply into state sovereign processes, and prohibited conduct the Constitution permits. ${ }^{122}$ And yet, the Boerne cases did not purport to overrule the VRA precedent. To the contrast, the new decisions explicitly left the older ones largely intact. ${ }^{123}$ Boerne cited the provisions upheld in the VRA cases from South Carolina v. Katzenbach through City of Rome as examples of permissible enforcement legislation, despite both "the burdens those measures placed on the States" and their proscription of constitutional conduct. ${ }^{124}$ Boerne's progeny likewise invoked the earlier VRA provisions as examples of permissible congressional action, and cited the decisions upholding them as so establishing. ${ }^{125}$

The Boerne decisions, however, did not adequately distinguish the statutory provisions the earlier VRA decisions upheld from those the Court had now struck down. Boerne itself insisted that valid enforcement legislation did not require the elements that most obviously distinguished the VRA from the RFRA. ${ }^{126}$ Nor did the Court ever explain why it accorded so much deference to Congress in the early VRA cases and so little in the Boerne decisions. ${ }^{127}$ And while the Court may have simply been reluctant to overturn older, historically resonant decisions, ${ }^{128}$ just three years after Boerne, the Court again upheld the constitutionality of the VRA's preclearance obligation. Lopez v. Monterey County ${ }^{129}$ easily affirmed Congress's power "to guard against changes that give rise to a discriminatory effect" in covered jurisdictions, ${ }^{130}$ and emphasized that the Fifteenth Amendment permits "this intrusion" into state sovereignty. ${ }^{131}$ Justice Thomas dissented alone, arguing that the majority's construction of the VRA contravened the City of Boerne standard. ${ }^{132}$

Read together, Lopez and the Boerne cases show that the Rehnquist Court accepted broad congressional power to enact and reauthorize the VRA even as it curbed congressional power to enforce civil rights more generally. And although the Court never explicitly offered an explanation for this stance, Boerne itself provides a suggestion. The decision not only preserved the VRA precedent, but endorsed a critical rationale underlying it. One of the reasons Katzenbach v. Morgan had upheld section 4(e) of the VRA-which, recall, had banned particular English literacy tests-was that it promised to provide New York's Puerto Rican community with "enhanced political power [that] will be helpful in gaining nondiscriminatory treatment in public services... ."133 Boerne expressly affirmed the (p. 379) validity of this rationale, stating that the exercise of congressional power "rested on unconstitutional discrimination by New York... ."134 


\section{Enforcing the Fifteenth Amendment}

Notably, this "unconstitutional discrimination" had not been documented in the record supporting 4(e)'s enactment. It was, in fact, purely prospective. And yet, even as Boerne rejected Morgan's suggestion that Congress might define constitutional rights, it still endorsed Morgan's understanding of section 4(e) as a vehicle "to give Puerto Ricans 'enhanced political power' that would be 'helpful in gaining nondiscriminatory treatment in public services ... .'"135 In other words, Boerne agreed with Morgan that disenfranchisement increases the likelihood that those disenfranchised will confront discrimination in other realms. Boerne agreed that section 4(e) was an effort to diminish the prospect of such discrimination and thereby foster more responsive state governance. For this reason, deferring to Congress on the VRA comported with the Rehnquist Court's distinct views on federalism. It allowed intrusive federal intervention as a means to foster democratic accountability and hence provide the foundation for state primacy in a host of other areas. ${ }^{136}$ 


\section{Reauthorization and the Roberts Court}

Forty years after first enacting the VRA, Congress again voted to reauthorize the statute's expiring provisions. Following hearings held in 2005 and early 2006, Congress chose to maintain the statute's geographic reach, without adding or removing jurisdictions from coverage, and declined to ease bailout by eligible jurisdictions, despite several proposals that urged such action for reasons of policy and constitutional compliance. ${ }^{137}$ The few substantive changes Congress made restored the VRA to operate as it had before the Court adopted narrowing constructions in decisions from the early 2000s. ${ }^{138}$ The House passed 2006 reauthorization by a large margin; the vote in the Senate was unanimous.

As was widely expected, a Boerne-based challenge to the 2006 reauthorization came within days of its enactment. Opportunities for minority political participation had indisputably improved since Congress first crafted the statute, and so the question was whether the obstacles that persisted rose to the level Boerne and its progeny demanded. ${ }^{139}$ Complicating matters was the fact that, unlike the statutes invalidated in the Boerne cases, the VRA was not a new statute but one that had been operating for many years. This meant that conditions in the places where the VRA's reauthorized regional provisions applied (p. 380) needed to be evaluated in light of the regime's ongoing operational effect. More specifically, that evaluation needed to determine whether observable improvements signaled a problem solved or, instead, a problem kept in check by the very regulatory measures in place. ${ }^{140}$

By all measures, the Roberts Court seemed inclined to deem the problem solved. In 2006, Chief Justice Roberts and Justice Alito had replaced Chief Justice Rehnquist and Justice O'Connor, respectively, and the new justices seemed less inclined to support the VRA than their predecessors, who, admittedly, had already viewed the statute with considerable skepticism and only qualified support. ${ }^{141}$ At oral argument, for example, Chief Justice Roberts would colorfully equate the preclearance regime to an "elephant whistle," shooing away a nonexistent threat. ${ }^{142}$ But before that and even before the 2006 reauthorization became law, the new chief justice had reacted to a redistricting plan imposed as the consequence of the VRA with the observation, "it is a sordid business, this divvying us by race."143

Unlike the Rehnquist Court, however, the Roberts Court's discomfort with the VRA stems not simply from a considered distaste for majority-minority districts and the type of political participation they engender, but also from a less contextual objection to raceconscious decision-making of any sort. While the Rehnquist Court tolerated a good deal of such decision-making, ${ }^{144}$ the Roberts Court is more inclined to limit or dislodge mandates to consider race whenever it confronts them, regardless of whether the source is federal, state, or local law. As Chief Justice Roberts famously said, "The way to stop discrimination on the basis of race is to stop discriminating on the basis of race."145 


\section{Enforcing the Fifteenth Amendment}

This sentiment led the Roberts Court to reject a broad construction of section 2 of the VRA that would have increased the junctures in which districting officials needed to consider race to comply with the regime. Bartlett $v$. Strickland ${ }^{146}$ cabined the statute rather than expand opportunities for race-conscious decision-making. The decision limited the statute in this way even though it would cut off an application of the VRA that promised to foster cross-racial coalitions outside of majority-minority districts, and hence encourage a type of political participation the Rehnquist Court had once celebrated. ${ }^{147}$

(p. 381) The Roberts Court, moreover, has coupled its commitment to color-blindness with a preference for applying the Boerne doctrine rigorously. Late Rehnquist Court decisions had tempered Boerne and upheld statutes that would have fallen under the doctrine as originally employed, ${ }^{148}$ but the Roberts Court has made clear it favors the more demanding approach. ${ }^{149}$ This inclination, in turn, rendered the constitutional challenge to the 2006 VRA reauthorization even more serious.

Still, on its first pass at the issue, the Court chose to sidestep the constitutional question. Writing for the Court in Northwest Austin Municipal Utility District Number One v. Holder (NAMUDNO), ${ }^{150}$ Chief Justice Roberts expressed considerable skepticism about the continued need for the regime, ${ }^{151}$ and made clear that the Court stood ready to scrap the statute in the next case absent changed circumstances. ${ }^{152}$

Four years later, Shelby County v. Holder rendered the VRA's preclearance regime inoperative by scrapping the section 4 (b) coverage formula. ${ }^{153}$ Chief Justice Roberts's majority opinion concluded that the evidence of ongoing discrimination-as catalogued by Justice Ginsburg in her dissent ${ }^{154}$-was legally insufficient to justify the statute's continued regional application. ${ }^{155}$ As explanation, the chief justice noted that this discrimination was not as severe as it was when Congress first crafted the regime in 1965, that the changes in voter access and participation had not led Congress to alter the statute's preexisting coverage formula, and that contemporary discrimination encompassed conduct that differed from the conduct Congress listed in the coverage formula when it first subjected places to the regime's requirements. ${ }^{156}$

These observations were all true, but they also should have been irrelevant-at least under applicable doctrine the Shelby County majority did not purport to displace ${ }^{157}$ The fact that the misconduct documented in the 2006 record was not equivalent to the brazen defiance of constitutional norms that originally prompted Congress to enact the statute does not explain why the contemporary, unconstitutional discrimination Justice Ginsburg described could not be remedied in the manner Congress selected. The Warren Court recognized that Congress possessed nearly plenary authority when crafting such remedies. ${ }^{158}$ And even while the Rehnquist Court pulled back, it never suggested that prevalent constitutional violations should go unremedied simply because past conditions were worse than contemporary ones. ${ }^{159}$ Shelby County, by contrast, seemed to limit Congress's power to craft remedies for unconstitutional racial discrimination simply 


\section{Enforcing the Fifteenth Amendment}

because the discrimination fell short of the radical type that defined Alabama in 1965. But the Court did not explain why.

(p. 382) Nor did the Court make clear why Congress's decision to maintain the statute's preexisting coverage formula was constitutional error. To be sure, on a clean slate, a decision to regulate unregulated entities based on voter participation decades ago would be difficult to defend. One might well agree with the Court that had Congress "started from scratch in 2006, it plainly could not have enacted the present coverage formula."160 And yet, the Court was plainly wrong when it insisted "that is exactly what Congress has done." 161 Congress was decidedly not starting from scratch in 2006. Instead, it was confronted with the question whether a lawfully imposed remedial regime should continue.

Prior to Shelby County, there was extensive debate as to whether the record Congress assembled was adequate to support its decision to reauthorize the regime. The Shelby County majority, however, did not engage in that debate. It simply rejected the notion that Congress could have rationally concluded that current conditions justified preserving the existing coverage formula. But, standing alone, the fact that Congress chose to reauthorize the existing formula proves nothing. Insofar as the Court thought there was a mismatch between coverage and unconstitutional conduct, the Court needed to consider the record on its merits and explain both where it thought it was deficient and why the deference usually accorded Congress when finding facts did not apply. ${ }^{162}$ It did neither.

Finally, the fact that much of the 2006 record addressed so-called "second-generation" barriers such as racial vote dilution should have been of no consequence. Such barriers predated the VRA by decades and stood among the varied tactics used concurrently in the Jim Crow South to limit political participation by African-American citizens. ${ }^{163}$ Although Congress did not explicitly include these barriers in the section 4(b) coverage formula, the criteria it selected-namely, the use of tests and devices and low voter participation-were meant to capture the places that employed these very barriers. That is, the triggering criteria were not meant to limit the statute's reach but instead to capture places in which a broader range of conduct (including "second generation" conduct) had rendered the Fifteenth Amendment a nullity. In early decisions, the Court had explicitly recognized the statute to reach this conduct, ${ }^{164}$ and Congress repeatedly extended the statute with this understanding. And yet, the Shelby County majority insisted otherwise. In short, the reasons given by the Shelby County majority for section 4(b)'s invalidity do not explain why the provision had become invalid.

These articulated reasons, of course, do not prevent responsive action by Congress. And yet, the oddity of the Court's analysis complicates the task of crafting a constitutionally viable response, even if Congress proves willing to act. ${ }^{165}$ Shelby County managed to respond to a Boerne-based challenge without mentioning Boerne or the standard of review at all. Justice Thomas's concurring opinion argued that the majority's analysis rendered preclearance not just moot, but unconstitutional as well. ${ }^{166}$ While the majority opinion fell (p. 383) short of so holding, it was willing to immobilize a remedy Congress 


\section{Enforcing the Fifteenth Amendment}

crafted in the face of evidence of extensive ongoing discrimination that Justice Ginsburg described in detail and the majority did not question. That the majority did so despite the deference previously accorded to Congress in this context suggests serious limits now attach to Congress's power to enforce the Fifteenth Amendment.

\section{Conclusion}

Without doubt, preclearance had always been an unusual remedy, one that presumed public action was discriminatory rather than legitimate. It is certainly arguable that the Court's willingness to halt preclearance rested on the regime's distinctive features of coverage. ${ }^{167}$ If so, Congress would retain significant discretion to enforce the Fifteenth Amendment, and section 2 of the VRA could remain a fully viable, if notably imperfect, substitute for section 5. ${ }^{168}$ Put differently, the reservations voiced by the Roberts Court about congressional power and color-consciousness do not inexorably apply beyond the preclearance regime to future cases challenging electoral practices for their racially disproportionate impacts.

Indeed, Shelby County could be followed by a decision that embraces distinct congressional power to protect voting free from racial discrimination and other hindrances. Nearly a century and half ago, United States v. Reese ${ }^{169}$ struck down a key provision of a federal statute enforcing the Fifteenth Amendment despite undisputed evidence of unconstitutional racial discrimination in voting. Reese left room for Congress to remedy identified defects, and Ex parte Yarbrough followed, in which the Court recognized Congress's distinct and broad power to protect those rights essential to the healthy operation of government. The Roberts Court could do the same.

And yet, there is good reason to doubt that it will. Shelby County's toleration for unremedied or inadequately remedied discrimination, including, notably, discrimination that violates the Constitution, was not an isolated occurrence. Rather, it represents an increasingly common stance in the Roberts Court, evident in a range of cases that together suggest the Court thinks the contemporary civil rights regime does more harm than the discrimination it presently addresses, even when that discrimination is indisputably unconstitutional or otherwise invidious in nature. Under this view, existing civil rights laws do not simply make victims of undeniable discrimination whole, but instead place a host of interested parties, victims included, in a decidedly better position than they would have been had the discrimination never occurred. For this reason, the Roberts Court tends to view the regime as a costly and damaging enterprise that should be limited at every opportunity. ${ }^{170}$ The Roberts Court, accordingly, seems unlikely to identify the intersection of racial (p. 384) discrimination and the right to vote as a juncture in which Congress's judgments regarding remedies warrant particular respect. 
To be sure, recognition of congressional power does little absent congressional action. Yarbrough, for instance, brought no relief to African-American voters in the South, given that Congress failed for decades to exercise the broad power the decision identified. And yet, existing provisions of the VRA left untouched by Shelby County might be used to displace a wide array of discriminatory obstacles to political participation, even as they fall short of providing a full substitute for the preclearance regime. Their ability to do so, however, hinges on the Court's willingness to temper the rigorous stance it employed in Shelby County, and afford the regime Congress crafted more deference in future cases.

Congress presently looks like it possesses less power to enforce the Fifteenth Amendment than it ever has had before. But the Roberts Court still has work to do, and its stance on Congress's power to enforce the Fifteenth Amendment may yet evolve. Congress and the Court have worked cooperatively before, and they are sure to do so again. When a more cooperative stance will remerge and the goals it will advance remains to be seen.

\section{Bibliography}

Amar, A, The Bill of Rights (1998).

Benedict, M, 'Preserving Federalism: Reconstruction and the Waite Court' (1979) 1978 Supreme Court Review 39.

Brandwein, P, Rethinking the Judicial Settlement of Reconstruction (2013).

Burnham, W, 'The Changing Shape of the American Political Universe' (1965) 59 American Political Science Review 7-28.

Currie, D, The Constitution in the Supreme Court: The First Hundred Years (1985).

Davidson, C and Grofman, B (eds), Quiet Revolution in the South: The Impact of the Voting Rights Act, 1965-1990 (1994).

Fairman, C, Reconstruction and Reunion, 1864-1888 (1987).

Grofman, B, Handley, L and Niemi, R, Minority Representation and the Quest for Voting Equality (1992).

Hasen, R, 'Drafting a Proactive Bailout Measure for VRA Reauthorization' Election Law Blog (May 18, 2006 09:37 AM), http://electionlawblog.org/archives/005655.html.

Hills, R, 'Back to the Future? How the Bill of Rights Might Be about Structure after All' (1999) 93 Northwestern University Law Review 997.

Issacharoff, S, Karlan, P and Pildes, R, The Law of Democracy: Legal Structure of the Political Process (4 edn, 2012). 


\section{Enforcing the Fifteenth Amendment}

Karlan, P, 'Easing the Spring: Strict Scrutiny and Affirmative Action after the Redistricting Cases' (2002) 43 William and Mary Law Review 1569.

Katz, E, 'Reinforcing Representation: Congressional Power to Enforce the Fourteenth and Fifteenth Amendments in the Rehnquist and Waite Courts' (2003) 101 Michigan Law Review 2357-2358.

———. 'Reviving the Right to Vote' (2007) 68 Ohio State Law Journal 1163.

- - - 'Justice Ginsburg's Umbrella' in Bagenstos, S and Katz, E (eds), A Nation of Widening Opportunities? The Civil Rights Act at Fifty (forthcoming 2015).

(p. 385) Katz, E et al., 'Documenting Discrimination in Voting: Judicial Findings under Section 2 of the Voting Rights Act since 1982, Final Report of the Voting Rights Initiative' (2006) 39 Michigan Journal of Law Reform 643.

Keyssar, A, The Right to Vote: The Contested History of Democracy in the United States (2000).

Klarman, M, 'The White Primary Rulings: A Case Study in the Consequences of Supreme Court Decisionmaking' (2001) 29 Florida State University Law Review 55.

Kousser, J, The Shaping of Southern Politics: Suffrage Restrictions and the Establishment of the One-Party South (1974).

Pildes, R, 'The Politics of Race: Quiet Revolution in the South' (1995) 108 Harvard Law Review 1359 (book review).

-_- 'Democracy, Anti-Democracy, and the Canon' (2000) 17 Constitutional Commentary 295.

Siegel, R, 'From Colorblindness to Antibalkanization: An Emerging Ground of Decision in Race Equality Cases' (2011) 120 Yale Law Journal 1278.

Wang, X, The Trial of Democracy: Black Suffrage and Northern Republicans, 1860-1910 (1997). (p. 386)

\section{Notes:}

(1) 92 U.S. 214 (1875).

(2) 133 S. Ct. 2612 (2013).

(3) U.S. Const. amend. 15, section 2. See generally Keyssar, A, The Right to Vote: The Contested History of Democracy in the United States (2000) 93-104. 


\section{Enforcing the Fifteenth Amendment}

$\left({ }^{4}\right)$ Act of May 31, 1870, chapter 114, sections 1, 2, 3, 4, 6, 16 Stat. 140-41, repealed by 28 Stat. 36, 37 (1894); Enforcement Act of 1871, chapter 99, 16 Stat. 433 (1871);

Enforcement Act of 1871, chapter 22, 17 Stat. 13 (1871).

$\left({ }^{5}\right)$ Reese, n 1 above, 238-239 (Hunt, J, dissenting); ibid 216.

(6) Act of May 31, 1870, n 4 above, section 3.

$\left({ }^{7}\right)$ ibid section 4 .

$\left.{ }^{8}\right)$ Reese, n 1 above, 218, 220.

$\left({ }^{9}\right)$ Act of May 31, 1870, chapter 114, section 1, 16 Stat. 140.

$\left({ }^{10}\right)$ Act of May 31, 1870, chapter 114, sections 3, 4, 16 Stat. 140-41, repealed by 28 Stat. 36, 37 (1894).

(11) See Reese, n 1 above, 241 (Hunt, J, dissenting); Cong Globe, 41st Cong, 2d Sess 3663 (1870) (remarks of Senator Sherman); Fairman, C, Reconstruction and Reunion, 1864-1888 (1987) 231, 235 n.55, 250, 278.

(12) 92 U.S. 542 (1875).

(13) Cruikshank dismissed federal indictments that charged, inter alia, the defendants with having attacked their victims because they had voted and thus in violation of section 6 of the 1870 Act. See Act of May 31, 1870, chapter 114, section 6, 16 Stat. 140-41 (prohibiting interference with the "free exercise and enjoyment of any right or privilege granted or secured ... by the Constitution or laws of the United States"). Cruikshank dismissed this charge because the Court thought its indictments failed adequately to allege that the defendants had acted because of their victims' race. Cruikshank, n 2 above, 556 ("We may suspect that race was the cause of the hostility," but this racial intent "is not so averred.").

(14) Benedict, M, 'Preserving Federalism: Reconstruction and the Waite Court' (1979) 1978 Supreme Court Review 39, 73; Currie, D, The Constitution in the Supreme Court: The First Hundred Years (1985) 402; Fairman n 11 above, 278.

$\left({ }^{15}\right)$ Act of May 31, 1870, chapter 114, section 3, 4, 16 Stat. 140-41, repealed by 28 Stat. 36, 37 (1894).

(16) 92 U.S. 542, 554-555 (1876).

$\left({ }^{17}\right)$ See, e.g., Currie, n 14 above, 295-296; Mathews, J, Legislative and Judicial History of the Fifteenth Amendment (1909) 103; Katz, E, 'Reinforcing Representation:

Congressional Power to Enforce the Fourteenth and Fifteenth Amendments in the Rehnquist and Waite Courts' (2003) 101 Michigan Law Review 2357-2358. For a similar argument, see Brandwein, P, Rethinking the Judicial Settlement of Reconstruction (2013). 
(18) 110 U.S. 651 (1884).

$\left({ }^{19}\right)$ ibid 665-666; see also Brief for Petitioners at 11, Ex Parte Yarbrough, 110 U.S. 651 (1884) (No 75).

$\left({ }^{20}\right)$ Yarbrough, n 19 above, 666 (referring to the Civil Rights Cases, 109 U.S. 3 (1883), and United States v. Harris, 106 U.S. 629 (1883)).

(21) Yarbrough, n 19 above, 667.

$\left({ }^{22}\right)$ ibid.

(23) 100 U.S. 303 (1879).

(24) See, e.g., Ex parte Virginia, 100 U.S. 339, 369 (1879) (Field, J, dissenting); see also Amar, A, The Bill of Rights (1998) 273-274.

(25) 100 U.S. at 308.

$\left({ }^{26}\right)$ Hills, R, 'Back to the Future? How the Bill of Rights Might Be about Structure after All’ (1999) 93 Northwestern University Law Review 997, 997, 999, 1000.

$\left({ }^{27}\right)$ ibid 997.

(28) Yarbrough, n 19 above, 666.

(29) Wang, X, The Trial of Democracy: Black Suffrage and Northern Republicans, 1860-1910 (1997) 250-251; Welch Jr., R, "The Federal Elections Bill of 1890: Postscripts and Prelude' (1965) 52 Journal of American History 511, 511 (explaining that defeat for the 1890 bill "more clearly marked the acceptance of Negro subjugation than the culmination of sectional reconciliation").

$\left.{ }^{30}\right)$ Keyssar, n 3 above.

( $\left.{ }^{31}\right)$ Hunter v. Underwood, 471 U.S. 222 (1985); Harman v. Forssenius, 380 U.S. 528 (1965); United States v. Louisiana, 225 F. Supp. 353 (E.D. La. 1963), aff'd, 380 U.S. 145 (1965); see also Pildes, R, 'Democracy, Anti-Democracy, and the Canon' (2000) 17 Constitutional Commentary 295, 301-302.

(32) Kousser, J, The Shaping of Southern Politics: Suffrage Restrictions and the Establishment of the One-Party South (1974) 238-265.

(33) See Issacharoff, S, Karlan, P and Pildes, R, The Law of Democracy: Legal Structure of the Political Process (4 edn, 2012) 103.

(34) Wang, n 29 above, 254-259.

(35) Act of May 31, 1870, chapter 114, section 5, 16 Stat. 140-41. 


\section{Enforcing the Fifteenth Amendment}

(36) 190 U.S. 127, 139 (1903). The Court also held that the indictments failed adequately to ascribe a racial motivation for the conduct charged.

$\left({ }^{37}\right)$ ibid 140. James v. Bowman did not question Congress's power to proscribe bribery in federal elections, the absence of state action notwithstanding. But while the election in dispute was, in fact, a congressional election, the statute itself referenced the Fifteenth Amendment as the source under which Congress had acted. The Court insisted it was unable to limit the statute to federal elections, and thus allow it to serve another purpose from the one for which it was enacted.

(38) ibid 136-139.

(39) Yarbrough, n 19 above, 666.

$\left({ }^{40}\right)$ Giles v. Harris, 189 U.S. 475, 482 (1903).

$\left({ }^{41}\right)$ ibid 488 . The Court also professed an inability both to invalidate the regime and order Giles registered under a "void instrument." ibid 486.

$\left({ }^{42}\right)$ ibid 488.

$\left({ }^{43}\right)$ Giles v. Teasley, 193 U.S. 146 (1904).

(44) HR Rep No 1740, at 3 (1904); Issacharoff et al., n 33 above, 103.

$\left.{ }^{45}\right)$ HR Rep No 1740, at 3.

$\left({ }^{46}\right)$ Wang, n 29 above. Sections 1, 6, and 17 of the 1870 Act remained standing.

$\left({ }^{47}\right)$ Pildes, n 31 above, 311, 313-317. But see Klarman, M, 'The Plessy Era' (1998) 1883 Supreme Court Review 303.

$\left({ }^{48}\right)$ Keyssar, $n 3$ above, 168-169; Burnham, W, "The Changing Shape of the American Political Universe' (1965) 59 American Political Science Review 7, 7-28.

(49) Colegrove v. Green, 328 U.S. 549 (1946).

$\left({ }^{50}\right)$ Breedlove v. Suttles, 302 U.S. 277 (1937).

(51) A limited exception was the Soldiers Voting Acts of 1942 and 1944, which permitted absentee soldiers serving on military bases and abroad to register and vote without paying local poll taxes. For a discussion, see Keyssar, n 3 above, 246-247 (describing exemption as an "important step" in bringing down the poll tax in that the "federal government's disapproval of poll taxes had become a matter of law").

(52) Lane v. Wilson, 307 U.S. 268 (1939); Guinn v. United States, 238 U.S. 347 (1915).

(53) See Terry v. Adams, 345 U.S. 461 (1953); Smith v. Allwright, 321 U.S. 649 (1944). 


\section{Enforcing the Fifteenth Amendment}

$\left({ }^{54}\right)$ Gomillion v. Lightfoot, 364 U.S. 339 (1960).

( $\left.{ }^{55}\right)$ See Klarman, M, 'The White Primary Rulings: A Case Study in the Consequences of Supreme Court Decisionmaking' (2001) 29 Florida State University Law Review 55.

(56) Pub. L. No 85-315, 71 Stat. 637 (1957).

$\left({ }^{57}\right)$ Pub. L. No 86-449, section 301, 74 Stat. 90 (1960).

(58) E.g., S Rep No 109-295, at 11-12 (2006).

$\left({ }^{59}\right)$ Keyssar, n 3 above, 262-265.

$\left({ }^{60}\right)$ ibid 263.

(61) S Rep No 109-295, at 1.

( $\left.{ }^{62}\right) 42$ U.S.C. section 1973b(b) (2006).

$\left({ }^{63}\right)$ ibid.

(64) ibid section 1973b(a).

$\left({ }^{65}\right)$ ibid section $1973 b(b)$.

$\left.{ }^{66}\right)$ Initially, these provisions applied to Alabama, Alaska, Georgia, Louisiana, Mississippi, South Carolina, and Virginia as well as specific political subdivisions in Arizona, Hawaii, Idaho, and North Carolina.

$\left({ }^{67}\right)$ Brief for Plaintiff at 4-5, South Carolina v. Katzenbach, 383 U.S. 301 (1966) (No 22), 1965 WL 130083, at *4-5.

(68) 383 U.S. 301, 327-328 (1966).

$\left({ }^{69}\right)$ ibid 329.

$\left({ }^{70}\right)$ ibid 328, 334.

$\left({ }^{71}\right)$ ibid 328.

$\left.{ }^{72}\right)$ ibid.

(73) See, e.g., Katzenbach v. Morgan, 384 U.S. 641, 651 (1966); see also United States v. Guest, 383 U.S. 745, 783-784 (1966) (Brennan, J, concurring).

( ${ }^{74)}$ See Katzenbach, n 73 above.

( $\left.{ }^{75}\right) 42$ U.S.C. section $1973 \mathrm{~b}(\mathrm{e})$.

(76) 384 U.S. 641 (1966). 
$\left.{ }^{77}\right)$ ibid 654-655.

$\left.{ }^{78}\right)$ ibid 653.

$\left.{ }^{79}\right)$ ibid 654 .

${ }^{(80)}$ ibid 653.

$\left.{ }^{81}\right)$ ibid.

$\left.{ }^{82}\right)$ ibid.

${ }^{(83)}$ Allen v. Board of Elections, 393 U.S. 544, 566-567 (1969).

$\left.{ }^{84}\right)$ Keyssar, n 3 above, 264.

( $\left.{ }^{85}\right)$ See, e.g., Mobile v. Bolden, 446 U.S. 55, 65 (1980).

$\left.{ }^{86}\right)$ Voting Rights Act Amendments of 1970, Pub. L, No 91-285, 84 Stat. 314, 315; Act of Aug. 6, 1975, Pub. L. No 94-74, 89 Stat. 400 (1975).

$\left.{ }^{87}\right) 84$ Stat. $314,315$.

(88) S Rep No 94-295, at 8-9 (1975).

${ }^{(89)}$ Oregon v. Mitchell, 400 U.S. 112 (1970). The Court did strike down one provision in the 1970 extension, namely, Congress's effort to lower the voting age to eighteen in state and local elections. Three justices would have struck down the provision's application to federal elections as well. ibid 281 (Stewart, J, dissenting in part).

${ }^{(90)} 400$ U.S. at 133.

$\left({ }^{91}\right) 400$ U.S. at 234-235 (Brennan, J, dissenting in part).

$\left({ }^{92}\right) 400$ U.S. at 284 (Stewart, J, dissenting in part).

(93) 446 U.S. 156 (1980).

(94) ibid 173.

(95) 446 U.S. 55 (1980).

(96) ibid 67-68, 80.

(97) 446 U.S. at $175-176$.

${ }^{(98)}$ ibid 177.

$\left({ }^{99}\right)$ ibid 193 (Powell, J. dissenting); ibid 206 (Rehnquist, J. dissenting, with Stewart, J.). (100) 42 U.S.C. section 1973(a) (2000). 


\section{Enforcing the Fifteenth Amendment}

$\left({ }^{101}\right)$ See White v. Regester, 412 U.S. 755 (1973); Zimmer v. McKeithen, 485 F.2d 1297 (1973).

(102) Thornburg v. Gingles, 478 U.S. 30 (1986); see also Grofman, B, Handley, L and Niemi, R, Minority Representation and the Quest for Voting Equality (1992) 47-49.

(103) Gingles, n 102 above, 50 (requiring that plaintiffs also demonstrate that the group is politically cohesive and that the white majority votes sufficiently as a bloc to defeat the minority-preferred candidate).

(104) See, e.g., Katz, E et al., 'Documenting Discrimination in Voting: Judicial Findings under Section 2 of the Voting Rights Act since 1982, Final Report of the Voting Rights Initiative' (2006) 39 Michigan Journal of Law Reform 643, 660.

(105) See Bone Shirt v. Hazeltine, 461 F.3d 1011, 1019 (8th Cir. 2006); see also Katz, E, 'Reviving the Right to Vote' (2007) 68 Ohio State Law Journal 1163, 1165, 1178-1179.

(106) See generally Keyssar, n 3 above, 238-239.

$\left({ }^{107}\right)$ See Beer v. United States, 425 U.S. 130 (1976).

(108) See Reno v. Bossier Parish School Board, 520 U.S. 471, 476 (1997); see also 28 C.F.R. section 51.55(b)(2) (1996), modified by 28 C.F.R. section 51.55(b) (2012).

(109) See Bush v. Vera, 517 U.S. 952 (1996); Miller v. Johnson, 515 U.S. 900 (1995).

(110) Keyssar, n 3 above, 294-295.

(111) See Pildes, R, 'The Politics of Race: Quiet Revolution in the South' (1995) 108 Harvard Law Review 1359, 1364-1365 and n.31 (book review).

(112) See, e.g., The Help American Vote Act of 2002, 42 U.S.C. sections 15301-15545; The National Voter Registration Act of 1993, 42 U.S.C. section 1973gg-2; The Civil Rights Act of 1991, 42 U.S.C. section 1981; The Americans with Disabilities Act, 42 U.S.C. section 12101 (1990).

(113) See, e.g., City of Rome v. United States, 446 U.S. 156, 211-212, 218-220 (1980) (Rehnquist, J, dissenting); United Jewish Organizations v. Carey, 430 U.S. 144, 172-174 (Brennan, J, concurring).

(114) See, e.g., Georgia v. Ashcroft, 539 U.S. 461 (2003); Johnson v. De Grandy, 512 U.S. 997 (1994).

(115) See, e.g, Ashcroft, n 114 above; Reno v. Bossier Parish School Board, 528 U.S. 320 (2000); Reno v. Bossier Parish School Board, n 108 above; Abrams v. Johnson, 521 U.S. 74 (1997); Holder v. Hall, 512 U.S. 874 (1994); DeGrandy, n 114 above, 1022; Presley v. Etowah County Commission, 502 U.S. 491 (1992). 


\section{Enforcing the Fifteenth Amendment}

(116) See, e.g., Shaw v. Reno, 509 U.S 630, 652 (1993); see also Vera, n 109 (above); Miller, n 109 (above).

$\left.{ }^{117}\right)$ See notes above and accompanying text.

(118) 521 U.S. 507, 520 (1997).

(119) See, e.g., Board of Trustees of the University of Alabama v. Garrett, 531 U.S. 356, 370 (2001); Kimel v. Florida Board of Regents, 528 U.S. 62, 90 (2000); see also Garrett, 531 U.S. at 375-376 (Kennedy, J, concurring).

$\left({ }^{120}\right)$ Kimel, n 119 above, 82-83 (ADEA); Garrett, n 119 above, 365, 372 (ADA); United States v. Morrison, 529 U.S. 598, 625-626 (2000) (the Violence against Women Act); College Savings Bank v. Florida Prepaid Postsecondary Education Expense Board, 527 U.S. 666 (1999) (the Trademark Remedy Clarification Act); Florida Prepaid Postsecondary Education Expense Board v. College Savings Bank, 527 U.S. 627, 639-641 (1999) (the Patent and Plant Variety Protection Remedy Clarification Act).

$\left({ }^{121}\right)$ See Kimel, not 119 above, 91; Florida Prepaid v. College Savings Bank, n 120 above, 640; Boerne, n 118 above, 531.

(122) See Katz, n 17 above, 2366 nn.143-145.

(123) Boerne rejects Katzenbach v. Morgan's suggestion that Congress may "ratchet up" constitutional protections as construed by the Court. Boerne, n 118 above, 527-558; Katzenbach v. Morgan, n 73 above, 648-649 (1966) (holding that Congress's section 5 power is limited to remedying violations of constitutional rights as defined by the Court).

(124) Boerne, n 118 above, 518.

(125) See Nevada Department of Human Resources v. Hibbs, 538 U.S. 721, 735-736 (2003); Garrett, n 119 above, 373; Morrison, n 120 above, 626; Kimel, n 119 above, 89; College Savings Bank v. Florida Prepaid, n 120 above, 639 n.5.

(126) Boerne, n 118 above, 533.

(127) Katz, n 17 above, 2368 n.156.

(128) Karlan, P, 'Easing the Spring: Strict Scrutiny and Affirmative Action after the Redistricting Cases' (2002) 43 William and Mary Law Review 1569, 1594 (suggesting that the Court "has been unwilling to use strict scrutiny to dismantle [the VRA,] the crown jewel of the Second Reconstruction").

(129) 525 U.S. 266 (1999).

$\left({ }^{130}\right)$ ibid 283.

$\left.{ }^{131}\right)$ ibid. 284-285. 


\section{Enforcing the Fifteenth Amendment}

(132) ibid 294-297 (Thomas, J., dissenting).

(133) 384 U.S. $641,652$.

${ }^{(134)}$ Boerne, n 118 above, 528.

(135) ibid (quoting Katzenbach v. Morgan, n 73 above, 652).

(136) Katz, n 17 above, 2388 nn. 276-277.

(137) See 152 Cong. Rec. H5198 (Westmoreland amendment); Hasen, R, 'Drafting a Proactive Bailout Measure for VRA Reauthorization' Election Law Blog (May 18, 2006 09:37 AM), http://electionlawblog.org/archives/005655.html.

(138) See Fannie Lou Hamer, Rosa Parks, and Coretta Scott King Voting Rights Act Reauthorization and Amendments Act of 2006, Pub. L. No. 109-246, § 2(b)(6), 120 Stat. 577, 578 (2006) (overturning Georgia v. Ashcroft and Reno v. Bossier Parish School Board).

(139) See Complaint, Northwest Austin Municipal Utility District No. 1 v. Mukasey, 573 F. Supp. 2d 221 (D.D.C. 2008) (No. 06-CV-1384) (filed August 4, 2006, just eight days after the enactment of the 2006 VRA amendments).

$\left({ }^{140}\right)$ Katz, E, 'Dismissing Deterrence' (2014) 127 Harvard Law Review Forum 248.

$\left({ }^{141}\right)$ See above. Compare also Ricci v. DeStefano, 557 U.S. 557, 596 (Alito, J., concurring) with Bush v. Vera, 517 U.S. 972, 990 (O’Connor, J., concurring).

$\left({ }^{142}\right)$ See, e.g., Transcript of Oral Argument at 28, Northwest Austin, n 139 above ("Well, that's like the old-you know, it's the elephant whistle. You know, I have this whistle to keep away the elephants. You know, well, that's silly. Well, there are no elephants, so it must work.").

$\left({ }^{143}\right)$ League of United Latin American Citizens [LULAC] v. Perry, 548 U.S. 399, 511 (2006) (Roberts, C.J., concurring). Curiously, the chief justice read the VRA more expansively than did the majority, albeit in a way that would have allowed Texas to remove one hundred thousand Latino voters from a congressional district to prevent them from voting against a vulnerable incumbent. See ibid 442; see also Katz, n 105 above, 1163-1164.

( $\left.{ }^{144}\right)$ See, e.g., Ashcroft, n 114 above; Miller, n 109 above. See also Siegel, R, 'From Colorblindness to Antibalkanization: An Emerging Ground of Decision in Race Equality Cases' (2011) 120 Yale Law Journal 1278, 1292-1293 (describing the Rehnquist Court's willingness to "tolerate[] and even encourage[]" certain types of "race-conscious interventions" in the 1980s and 1990s).

$\left({ }^{145}\right)$ Parents Involved in Community Schools v. Seattle School District No. 1, 551 U.S. 701, 748 (2007). 
(146) 556 U.S. 1 (2009).

$\left({ }^{147}\right)$ De Grandy, n 114 above.

${ }^{(148)}$ Hibbs, n 125 above, 727-735.

(149) See Coleman v. Court of Appeals of Maryland, 132 S. Ct. 1327, 1333-1334 (2012).

(150) 557 U.S. 193 (2009).

$\left.{ }^{151}\right)$ ibid 201-204.

(152) Katz, E, 'From Bush v. Gore to NAMUDNO: A Response to Professor Amar' (2009) 61 Florida Law Review 991.

(153) 42 U.S.C. section 1973b(b) (2006).

(154) See Shelby County v. Holder, 133 S. Ct. 2612, 2639-2643, 2646-2647 (2013)

(Ginsburg, J., dissenting).

$\left({ }^{155}\right)$ See ibid 2619, 2629-2631.

(156) ibid 2629-2631.

(157) See Katz, E, 'What Was Wrong with the Record?' (2013) 12 Election Law Journal 329 (2013).

${ }^{(158)}$ Katzenbach, n 73 above; South Carolina v. Katzenbach, n 67 above.

(159) Boerne, n 118 above.

(160) Shelby County, n 154 above, 2630.

${ }^{(161)}$ ibid 2631.

(162) Katz, n 157 above.

(163) See generally Davidson, C and Grofman, B (eds), Quiet Revolution in the South: The Impact of the Voting Rights Act, 1965-1990 (1994).

(164) Allen v. Board of Elections, 393 U.S. 554, 567 (1969); see also ibid 566-577 (stressing that preclearance was meant " 'to be all-inclusive of any kind of practice,' " and to be given "the broadest possible scope").

$\left({ }^{165}\right)$ One has now been proposed, see H.R. 3899: Voting Rights Amendments Act of 2014, Congress.gov, http://beta.congress.gov/bill/113th-congress/house-bill/3899 (last visited June 25, 2014), that is of more limited reach than the preclearance regime it purports to replace.

(166) See Shelby County, n 154 above, 2612, 2631-2632 (Thomas, J., concurring). 


\section{Enforcing the Fifteenth Amendment}

$\left({ }^{167}\right)$ See South Carolina v. Katzenbach, n 67 above, 327.

(168) Brief for the Federal Respondent at 10-11, 39-41, 50-53, Shelby County, n 154 above; see also Brief of Amici Curiae Ellen D. Katz and the Voting Rights Initiative in Support of Respondents, ibid.

(169) 92 U.S. 214 (1875).

$\left({ }^{170}\right)$ See Katz, E, 'Justice Ginsburg's Umbrella' in Bagenstos, S and Katz, E (eds), A Nation of Widening Opportunities? The Civil Rights Act at Fifty (forthcoming 2015).

\section{Ellen D. Katz}

University of Michigan Law School 